\title{
THE COMPETITIVENESS OF BUSINESS GROUPS AND THEIR AFFILIATES IN INTERNATIONAL OPERATIONS
}

\author{
Roderick Caballero BUGADOR \\ Hankuk University of Foreign Studies, Yongin, SOUTH KOREA \\ rbugador@hufs.ac.kr
}

\begin{abstract}
The discourse on the competitiveness of emerging economy firms continues with globalization. This paper joins the dialogue by providing a framework of the competitiveness of business groups and their affiliates in international operations. The goal is to address the vast literature on emerging economies that remains short in providing the theoretical background on the competitiveness of emerging and transitioning economy firms. To do this, this study used a critical review and analysis of the literature. It offers some propositions to illustrate the applicability of the framework in analyzing the international expansion of business group affiliates across borders. Ultimately, the paper contributes to the literature on managerial capabilities and competitiveness of firms to sustain their operations as the new emerging economy multinationals.
\end{abstract}

Keywords: emerging economy firms, competitive advantages, Business Group advantages, affiliatelevel advantages, capabilities.

\section{Introduction}

The literature on emerging economies ${ }^{1}$ faces limitations in understanding the characteristics of emerging economy firms ${ }^{2}$ and their competitive advantages. It also neglects the issues on the evolutionary tendencies of such firms and their advantages, that is, their subsequent development and strenghtening across borders (Contractor, 2013; Cuervo-Cazurra, 2012). Adding to this is the limited discrimination on the types of emerging economy firms, particularly their organizational structure, as different organizational structures result in different types of competitive advantages (Rama-murti \& Singh, 2009). This paper deals with the above issues in two ways.

First, it focuses on a cer-tain type of emerging economy firms with a unique organizational structure, that is, the business group (hereafter also abbreviated as $B G$ or $B G s$ ), and second, it provides a theoretical explanation of their competitive

\footnotetext{
${ }^{1}$ Emerging economies are economies or countries that are considered to be neither underdeveloped nor advanced (Ramamurti \& Singh, 2009; UNCTAD, 2010). These are the countries that recently demostrated faster growth in response to the globalizing world economy; some examples are the BRICS countries or Brazil, Russia, India, China, and South Africa.

${ }^{2}$ Emerging economy firms are firms coming from, or whose home countries are, the emerging countries.
}

advantages and the subsequent enhance-ment and evolution of such advantages.

The objective is to clarify the characteristics of BGs, as a particular type of emerging economy firm, so that a more comprehensive understanding of the emerging economy firms and their competitiveness can be advanced.

As a type of emerging economy firm, $\mathrm{BG}$ is the persistent and most intermediate form of enterprise in emerging economies. What is enigmatic about this organization is its inherent competitive advantages compared to other firms in these economies. Although inconclusive, empirical evidence suggests that firms belonging to BGs, mostly in a domestic setting, perform better than non-BG or stand-alone firms (Carney, Gedajlovic, Heugens, Van Essen, \& Van Oosterhout, 2011; Chacar \& Vissa, 2005; Chang \& Hong, 2000; Douma, George, \& Kabir, 2006; Khanna \& Rivkin, 2001). Indeed, most of the recent emerging economy firms that were successful in their internationalization attempts are BGaffiliated firms (UNCTAD, 2010). However, the mentioned competitive advantages of BGs and their affiliates do not have a clear theoretical explanation in the current literature. Thus, the literature has not caught up with the accelerated expansion of BGs across borders, as well as mentioning how they use their competi-tiveness vis-à-vis incumbent multi- 
nationals. To address this gap, this paper critically reviewed and analyzed the related literature on BGs in the fields of strategy, institutional economics, and international business.

Through the combination of different theories from related fields, this research came up with a potent theoretical framework that could explain the theoretical underpinnings of the specific advantages of BGs and their affiliates. The framework incorporated the established concepts of recombination and bundling and offers the concepts of "business group advantages," or the advantages derived at the group level, and "affiliate-level advantages," or those that are derived at the individual affiliate level. These concepts help to clarify the nature of the advantages of BGs in emerging economies and how these BGs and their affiliates develop such advantages in different, or a combination of, domestic and international markets. This is a significant step to clearly understand how emerging economy firms, particularly those with a structure of BG, would expoit and strenghten their global competitiveness.

\section{The advantages of emerging economy multinationals}

In recent years, there has been a substantial increase in outward foreign direct investment (OFDI) made by large enterprises from developing and emerging markets. They are conventionally called emerging economy multinationals (hereafter also abbreviated as EMNEs). In 2010, foreign direct investment (FDI) outflows from South, East, and Southeast Asia rose by $20 \%$ to about $\$ 230$ billion (UNCTAD, 2010). This in turn shifted the assessment of world trade activity to look more carefully on these internationalizing firms that could assume vital roles in the future vis-à-vis incumbent multinationals. This phenomenon attracted the interest of many researchers who try to explain their antecedents, competitiveness, and possible outcome (Goldstein \& Wells, 2007; Ramamurti \& Singh, 2009). Indeed, the evolution of economies results in the rise of new multinationals from different locations and changes to the old ones. There seems to be a rearranging of resources and advantages of firms at a global level.
One of the issues related to the EMNE phenomenon is the explanation on the nature of their competitive advantages as compared to those of the traditional advanced economy MNEs (Cuervo-Cazurra, 2012). In addition, their expansion across borders carries a different motivation compared to advanced economy MNEs, that is, asset seeking (Dunning, 2000), which projects a different developmental path. This is partly explained by the different institutional contexts of their home economies where they originated. Hence, different economies create different conditions for the interaction of institutions, market imperfections, and the development and exploitation of advantages (Gammeltoft, Barnard, \& Madhok, 2010). This is where the explanation of the disparity in the advantages and organizational configurations of both the advanced and emerging economy firms. In weaker economies where inefficiencies are common and scarcity of knowledge prevails, firms device a particular pattern of building advantages (Ramamurti, 2012). Firms may not be able, at some point, to acquire or own any valuable knowledge at all. The resulting advantages of stand-alone firm are not as strong compared to firms in the tacit knowledge creating advanced economies (Verbeke, 2009). The literature suggests that firms in these economies are only able to advance their knowledge or competencies through contractual access through alliances and joint ventures with the more advanced multinationals from developed economies (Amsden \& Hikino, 1994; Hobday, 1995). Therefore, the theoretical explanation of the rise of multinationals specific to particular locations, such as those from emerging economies, is captured by the general explanation of the dynamic evolution of firm-specific advantages (FSAs) and country-specific advantages (CSAs). To analyze the competitive advantages of EMNEs, it is useful to employ the FSA/CSA matrix (Rugman, 1981) to give an emphasis on the characteristics of each type of advantage that any EMNE would possess. Nonetheless, as a general principle, the FSA/CSA matrix offers an analysis of both the advantages at the same time. But, for simplicity, let us categorize EMNEs as having the tendency to follow three patterns of internationalization and multinationality: (1) FSA driven, (2) CSA driven, and (3) driven by interactions of FSAs and CSAs. 


\subsection{EMNEs driven by firm-specific advantages}

At the moment, there remains an issue about how the FSAs of EMENEs influence their speed of internationalization or becoming multinationals, for example, acceleration and mode of entry. FSAs are defined as unique capabilities proprietary to the firm. They may be built on products or process technology and marketing or distributional skills (Rugman, 1981). In the literature, FSAs are assumed to exist before a firm embarks to internationalization. Dunning (1980) captured this through his eclectic paradigm or the OLI framework, which identifies the firm's ownership advantages (O) or FSAs, locational advantages (L), and internalization advantages (I). $\mathrm{He}$ argued that these three advantages and their combinations are able to explain the investment patterns of firms' direct investment or FDI in international markets. The eclectic paradigm suggests that firms develop their ownership advantages at home country and then transfer them to other countries, where there are also complementary resources, through FDI. This will eventually lead to their multinationality. On the other hand, other theories in international business such as the Uppsala model suggests that the internationalization process takes time because of investment risk and commitment coupled with organizational learning (Johanson \& Vahlne, 1977). Those that can learn faster and offset their liability of foreignness, by possession of superior advantages, are likely to succeed in their internationalization attempts (Hymer, 1976; Zaheer, 1995). However, as suggested by Li (2007), the internationalization processes of recent EMNEs do not follow the Uppsala model or Dunning's OLI model. Instead they follow a catch-up strategy by accelerating their entry in the international markets (Bonaglia, Goldstein, \& Mathews, 2007; Kumaraswamy, Mudambi, Saranga, \& Tripathy, 2012). Some suggest that this catch up was possible because of the accumulated knowledge of these firms in international markets through their previous contractual projects with incumbent MNEs (Buckley, Cross, Tan, Xin, \& Voss, 2008; Hobday, 1995). But, these catch-up managerial capabilities still lag behind with the knowledge-based FSAs of the advanced economy firms. Nonetheless, we can argue that the FSAs of emerging market firms have reached a certain level of sophistication that is adequate to function in a specific international market or industry.

\subsection{EMNEs driven by country-specific advantages}

The newly liberalized countries, especially China and India, deliberately heightened the speed of internationalization of their firms using different motives or strategies. Home country condition is one of the major drivers of the internationalization (Witt \& Lewin, 2007). Home country formal institutions, which shield domestic firms from stiff competition with MNEs, hasten their local resource acquisition activities. The case of Chinese emerging multinationals is a classic example of home country driven internationalization facilitated by government policy. Beginning the 1980s, the Chinese government pursued economic reform by transforming and restructuring state enterprises into large enterprises (Yiu, 2011). Countries that liberalized believe that the accelerated internationalization provides their firms with an opportunity to secure strategic assets and build capabilities and turn their 'latecomer' status into a source of competitive advantage (Luo \& Tung, 2007). In addition, some firms relied heavily on CSAs such as endowments of capital from their government to ease their mode of entry such as acquisition or greenfield (Rugman, 2009). Here we see the influence and ownership advantages of countries and institutions influencing the organizational dynamics of firms.

\subsection{EMNEs driven by the interaction of FSAs and CSAs}

As firms and countries evolve, advantages evolve as well. The evolution of these advantages is basically the derivative of FSAs and CSAs. On their own, these advantages interdependently exist among other advantages derived from the dynamic interaction of FSAs and CSAs over time (Cuervo-Cazurra \& Genc, 2008; Erramilli, Agarwal, \& Kim, 1997; Gammeltoft et al., 2010; Henisz, 2003). Some of these advantages are based on institutions, netwroks, and relationships. Most of them evolved differently compared to the typical knowledge-based FSAs or high-technology assests. A variant of these advantages, which can be found among firms in emerging economies, is the advantage that is developed 
by BGs that arise from their unique organizational structure out of the interaction of the FSAs and CSAs, together with the capabilities of BG affiliates. This advantage goes beyond the firm-level advantages and stems from the accumulated knowledge that has been captured, owned, and controlled by the BG overtime (Demsetz, 1988; Dierickx \& Cool, 1989; Mahmood, Zhu \& Zajac, 2011; Rugman \& Verbeke, 1992; Teece, Pisano \& Shuen, 1997).

This type of advantage arises from the managerial capabilities in dealing with different levels of institutional voids and market imperfections, which are prevalent in developing and emerging economies (Chang \& Choi, 1988; Khanna \& Rivkin, 2001; Kock \& Guillén, 2001; Leff, 1978). BG-affiliated firms exhibit a dynamic mechanism in combining the relative CSAs and FSAs of all the affiliates within the BG. This combination offers a different level and type of advantages that are only available to firms affiliated to BGs.

\section{Theoretical framework and propositions on the competitiveness of business groups}

There are competing perspectives in explaining the antecedents of the BG's structure and its inherent advantages that are transferred to its affiliates. The rationale of the formation of BGs varies depending on the conditions of the economy and immediate environment; it can be deliberate or otherwise. The rationales are considered as exogenous and endogenous force explanations (Colpan, Hikino \& Lincoln, 2010). The exogenous force explanation includes the perspectives that look at a number of conditions that create supply and demand for BGs to emerge. It can come from government policies, Institutional voids (Khanna \& Palepu, 1997), cultural embeddedness, (Granovetter, 1995) and asymmetric foreign trade and investments (Guillén, 2000). Endogenous force explanation focuses on how BGs as economic organizations organize their resources and capabilities from within the boundaries of the group (Chang \& Hong, 2000; Leff, 1978; Penrose, 1959). Their strategy of repeatedly entering industry by industry enabled them to form a highly diversified organization and continue to expand in a routinely spider web pattern (Amsden \& Hikino, 1994).
This paper builds on the endogenous explanation rather than the exogenous explanation of BG advantages. The reason is that exogenous explanations are types of environmental or institutional conditions that serve as inputs to the advantages of BGs and not the source of advantages themselves. The true advantages of BGs do not lie from these conditions but on their innovative response to such conditions, that is, internalization of market imperfections and endogenous capability building among the affiliates (Leff, 1978; Leibenstein, 1968; Mahmood et al., 2011). The problem with the exogenous explanations such as the lifecycle hypothesis (Strachan, 1976), institutional voids hypothesis (Khanna \& Palepu, 2000), and asymmetric trade argument (Guillén, 2000 ) is that it cannot predict the persistence and strengthening of BGs if and when the institutional voids or constraints disappear and when BGs are able to operate in multiple economies, that is, as multinationals, under varying institutional conditions. In reality, these institutional constraints actually work to the disadvantage of any firm as well as to BGs. Therefore, this paper follows that the existence and persistence of BGs, in domestic and international markets, lies in the dynamics of the functioning of their advantages that come from their group internal market. It is in their internal market where competitiveness is being developed and strengthened and thus serves as the key explanation of their existence and evolution over time.

\subsection{The elements of the competitive advantage of business groups}

The competitive advantages of BG-affiliated firms in emerging markets arise from the interaction of, and response to, specific country characteristics; imperfections in capital, labor, and product markets; and the recombination capabilities of the affiliate firms (Chang \& Choi, 1988; Chang \& Hong, 2000; Leff, 1978). These advantages are supported by the accumulated knowledge that has been captured, owned, and controlled by the BG over time (Dierickx \& Cool, 1989; Mahmood et al., 2011). This paper calls these advantages the business group advantages (hereafter also abbreviated as $B G A s$ ) as they accrue exclusively to BG-affiliated firms. The BGAs are internalized and found within the structure of $\mathrm{BG}$ and stored at the group level. As a BG is 
composed of independent affiliate firms, BGAs, in theory, can be found within each affiliate firm. They are particular type of advantages that express themselves owing to the interaction of a given external condition, such as market imperfections, and the coordinated and collaborative response among individual affiliate firms and their advantages. The resulting structure of BGAs can be found and distributed among the affiliates in the BG (see Fig. 1).

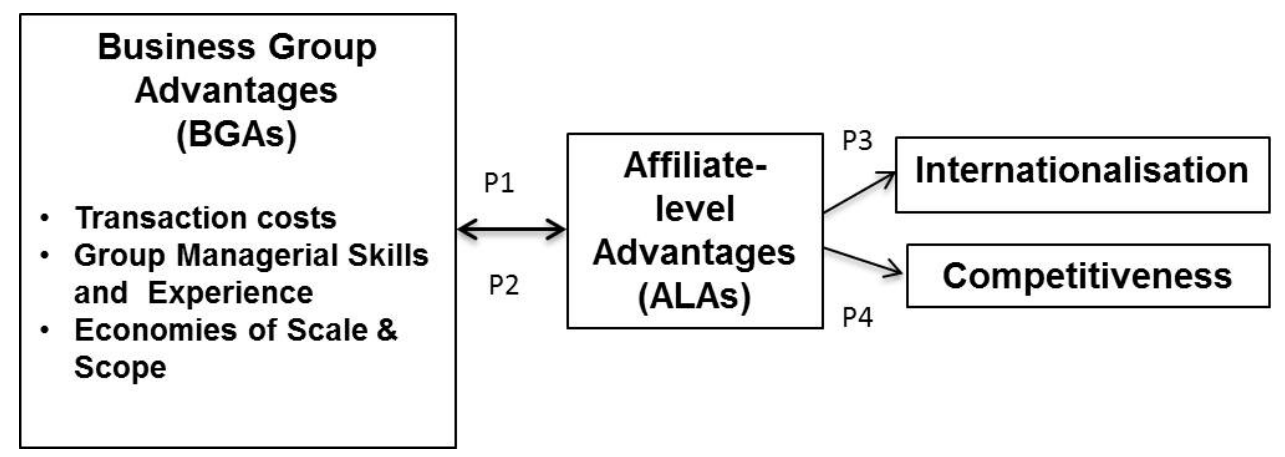

Figure 1. The internationalization and competitiveness of BG affiliates across borders

For operational purposes, this paper identified three generic components to describe the structure of BGAs that are transferred and interacted by the BG affiliates. These advantages are (1) reduced transaction costs through the group internal capital, labor, internal buying and selling, and market information search; (2) transferable group managerial skills and experience in product and geographical diversification, contacts and intermediation capabilities, and state relations; and (3) economies of scale and scope such as allocation and codevelopment of resources in the area such as research and development (R\&D)/technology and marketing and distribution, group brand, and reputation.

The BGA on transaction costs clearly explains the incentive of reducing the risks and costs for searching or developing information and advantages in the external market (Hennart, 1982; Leff, 1978; Williamson, 1981). The structure of BG provides an array of internal resources which an affiliate can exploit. For example, internal group capital is a very good source of capitalization for affiliates in times of investments, including foreign investments, and expansion (Gonenc, Kan \& Karadagli, 2007). Typically, BGs have affiliated holding companies that are entrusted to secure the administrative allocation of the group's financial resources.

As the external market is not the best option, BGs are swayed to withhold earnings and exploit such to its best economic use. This explains their capability to seize multiple portfolios, and their affiliates to expand businesses not only in domestic but also in international markets.

In the same manner, internal labor assures quality and fit of people within the whole organization. BGs in emerging markets operate training schools for grooming pools of employees within the group who will then be dispatched among the affiliates (Mahmood, Mitchell \& Chung, 2006). Through this, affiliate firms align their administrative structure and strategy with that of the group. Last but not the least, a steady supply of inputs and intermediate products is a crucial advantage of BG affiliates. In times of scarce supply and low demand, affiliate firms can tap an intragroup buying and selling linkages (Chang \& Hong, 2000). BGs rely on "internal suppliers" for their production input, skilled labor, and R\&D by which they bring in the same "house." Having a diversified structure permits BGs to increase the amount of their monopoly power over those who control or allocate resources, in particular industries or markets; some refer to this as "multimarket power" (Ghemawat \& Khanna, 1998).

On the other hand, the BGA on group managerial skills and experience provides a combination of context-specific and transferable skills among BG affiliates (Tan \& Meyer, 2010). Amsden and Hikino (1994) argued that the repeated industry-entry pat- 
terns of BGs were realized because of their "contact capabilities" with the state and foreign multinationals, followed by "project execution capabilities." According to them, these project execution capabilities refer "to the skills required to establish or expand operating and other corporate facilities, including undertaking preinvestment feasibility studies, project management, project engineering, procurement, construction, and startup operations." These capabilities are generic to BGs and not industry specific. They are difficult to trade because they are embodied in the owners, managers, and routines of the organization (Heugens \& Zyglidopoulos, 2008).

In addition, the experience of $\mathrm{BG}$ in the management of product and geographic diversification directly aid other affiliates in other potential product areas and locational expansions (Kim, Hoskisson, Tihanyi, \& Hong, 2004). This includes internationalization and alignment in the relevant global value chains. We can argue that the mode of international entry of BG affiliates can vary a lot and may have a different pattern compared to typical single firms. In some instances, the expansion of affiliates in related and unrelated product lines or geographical locations is a response to the circumstances or positions of other affiliates. Thus, we can see a kind of group internationalization as opposed to the usual singlefirm internationalization. Lastly, generic advantages of multiunit organizations or conglomerates, such as BG, are the economies of scope (Chandler, 1990; Colpan \& Hikino, 2010). The codevelopment of resources by group affiliates in the area such as R\&D and technology, marketing, and distribution provide leverage to all the affiliates in the group. A successful processing system that is developed by one affiliate may, at one point or another, be useful to another affiliate for benchmarking. Lead times and costs are reduced through this approach. Another important and unique BGA is group reputation. Group affiliates enjoy the ease of winning contracts or projects only because of their membership in a reputable BG. A BG might have a very long successful history of operations and transactional negotiations that create a positive halo effect to all the affiliates in the group. Hence, the control of such
BGA is not at the firm level but at the group level.

Proposition 1: The business group advantages transfer and influence the development of individual business group affiliate advantages

\subsection{The recombination of business group advantages and affiliate-level advantages}

The concept of BGA explains what kinds of advantages are found at the group level, but it does not explain all the potential advantages that are found at the individual affiliate level. This paper argues that what individual BG affiliates have are both the subset of the BGAs and affiliate-level advantages (hereafter also abbreviated as $A L A s$ ). ALAs are the unique resources, capabilities, and strengths that are specific to an affiliate firm. The ALA as a whole is a combination of the sharable BGA and the idiosyncratic resources and capabilities of an affiliate. By building on BGAs, affiliate firms can develop specific advantages independently. These advantages are unique resources, capabilities, and strengths specific to an affiliate firm (Barney, 1991). These BGAs and ALAs bundle is a function of the recombination capabilities by the individual affiliates (Teece, 2014; Teece, et al., 1997; Verbeke, 2009). This is very different from the simple concept of BG affiliation effects, because affiliation to BGs does not always guarantee advantages to individual affiliate firms. Therefore, this bundle defines the overall advantage of each individual affiliate as well as the heterogeneity of the affiliates within a BG (Rugman \& Verbeke, 1992). The variance among ALAs occurs because of the level and extent of BGA recombination by each affiliate, that is, some affiliates operationalize or depend on BGAs greater than others. This is because each affiliate has specific objectives, roles, operational scope, and eventually competitiveness. Hence, the affiliates can use the group structure to complement for the missing and potential advantages (Dyer \& Singh, 1998; Lavie, 2006; Mahmood, et al., 2011).

Proposition 2: The individual competitive advantages of business group affiliates depends on the extent of their recombination of business group advantages and affiliate-level advantages 


\subsection{The affiliate-level advantages and internationalization}

The existing literature on emerging economy BGs is not clear on the dynamics of the internationalization of BGs or why do we have business-group-affiliated multinationals within the BG. The literature partly suggests that the degree of internationalization of BGs and their affiliates is influenced by the moderating effects of BG affiliation (Chittoor \& Ray, 2007; Elango \& Pattnaik, 2007; Pananond \& Zeithaml, 1998; Tan \& Meyer, 2010; Yaprak \& Karademir, 2010). This paper expands the above literature and proposes that the internationalization of $\mathrm{BG}$ affiliates is a function of the recombiniation of BGAs and ALAs by BG affiliates. Hence, the BGA is positioned as one of the components of the overall advantages in the internationalization of BG affiliates. BG-affiliated firms recombine different types of advantages in their international expansion. In addition, affiliates also recombine these two advantages with country-specific advantages (CSAs) (Hennart, 2009; Rugman, 2009; Verbeke, 2009). This can be illustrated by looking at the strength and weakness of both BGAs and ALAs within the BG; Fig. 2 depicts this interactive dynamics.

\section{Business Group Advantages}

(BGAs)

\begin{tabular}{cc|c|c|}
\multicolumn{1}{c}{} & \multicolumn{1}{c}{ Weak } & Strong \\
\cline { 3 - 4 } $\begin{array}{c}\text { Affiliate-Level } \\
\text { Advantages } \\
\text { (ALAs) }\end{array}$ & Strong & 3 & 1 \\
\cline { 3 - 4 } & Weak & 4 & 2 \\
\cline { 3 - 4 } & & & \\
\cline { 3 - 4 } & &
\end{tabular}

Figure 2. The dynamics of the BGA-ALA recombination by business group affiliates

The axes represent two dimensions. The horizontal axis defines how strong or weak are the BGAs. These advantages are mostly available to affiliate firms in the BG. On the other hand, the vertical axis demonstrates the recombination capability of $\mathrm{BG}$ affiliates, that is, strong or weak. In general, the framework represents the four bundles of intragroup recombination by $\mathrm{BG}$ affiliates plus the assumed conditions of both home and host country CSAs. It suggests the heterogeneity of the BG affiliates as well as their propensity for internationalization. The first bundle, or quadrant 1 , is where both BGAs and ALAs are strong. In this bundle, an affiliate enjoys the best complementarities of BGAs and ALAs. These affiliates are somewhat the "core elites" or the "flagship firms" (Rugman \& D'Cruz, 2000; Yiu, Lu, Bruton, \& Hoskisson, 2007). For some reasons, these types of affiliates are likely to internationalize faster than the other affiliates. These affiliates have already crafted their ALAs to match the level of BGAs. The dependence on the BG is also strong here as the
BGA-ALA bundle complimented very well with each other. Examples are those affiliates that have strong $\mathrm{R} \& \mathrm{D}$ or production technologies but would tap the strong distribution system of the group to further reduce their costs. The second bundle, or quadrant 2 , is where BGAs are strong and ALAs are weak. Here, an affiliate mostly have BGAs and yet to start to develop its ALAs according to its role and operational objectives. This type of bundle requires the affiliate to build its advantages primarily on the BGAs. An example of this is an affiliate that has a potential to develop specific routines or products that goes well with its distinctive location and customer base. The affiliate is very dependent on the BG for support such as capital and information during their internationalization process. Hence, the group can play a very important role in the ALAs and internationalization decision on their affiliates (Elango \& Pattnaik, 2007).

The third bundle, or quadrant 3 , is where ALAs are strong and BGAs are weak. This type of bundle illus- 
trates the essence of the concept of "independence" among BG affiliates. Here, an affiliate is almost able to decide on its own primarily because of its specific scope and role within the BG. It builds more on its ALAs rather than on BGAs. This means that the resources and capabilities of certain affiliates are very specific to them, which can be attributed to their distinct recombination of bundled advantages over time. This type of bundle affords an affiliate to spinoff or relaxes its independence from the group. The examples of these are those BG-affiliated MNEs from Asia which serve as benchmarks for other affiliates (Chang, 2006). Some of these affiliates now operate in specialized industries whose technology is very different from the whole group. Finally, the fourth bundle, or quadrant 4 , is where both BGAs and ALAs are weak. This bundle essentially serves as supplements to the core affiliates and operates in the periphery. Here, the recombination capability is also weak. Affiliates which possess this bundle are unlikely to pursue internationalization. All four bundles also represent the competitive position of BG affiliates within the BG. Therefore, each bundle corresponds to a certain pattern of internationalization, including the variety of modes of entry and operational scope.

Proposition 3: The extent of the recombination of BGAs and ALAs by business group affiliates influences their degree of internationalization across borders

\subsection{The role of the foreign subsidiaries in enhancing the business group advantages}

The interactions and recombinations of BGAs, ALAs, and CSAs also bring new roles for BG and their foreign subsidiaries. The role of the BG parent firm is to marshal all their competitive advantages through intraorganizational recombinations, including the important complementary assets of the home country (Home CSAs), and transfer it to their foreign subsidiaries. The BG affiliates share significant support from their BGs while advancing their own ALAs in the multinational stage. These BGAs can be found in both the home country, through the other BG affiliates, and the host countries through other affiliates' subsidiaries. This thinking follows the new internalization theory as developed by Rug- man and Verbeke (1992, 2001), Hennart (2009), and Verbeke (2009), which distinguishes between advantages obtained in home and host countries. However, ALAs matter a lot here because of the combination of host country location-bound firmspecific advantages (LB FSAs) and its integration with the host country CSAs. The role of the parentaffiliate firms is to recombine all their advantages (as can be seen in Fig. 1), including the important complementary assets of the home country (home CSAs), and transfer it to their foreign subsidiaries. As a result, the foreign subsidiaries uniquely benefit from home and host country CSA recombination.

In addition, foreign subsidiaries obtain access to BGAs through the other affiliates' foreign subsidiaries in the same host countries. This type of advantage is called subsidiary-specific advantages (SSAs) (Rugman \& Verbeke, 2001). The SSAs are unique resources and capabilities owned or accessed by subsidiaries, which are, to some extent, distinct from those possessed by the parent affiliate firms (Birkinshaw, Hood \& Jonsson, 1998). Therefore, BG-affiliated foreign subsidiaries start to learn and acquire other capabilities that are very important in their multinational operations. This is strategic in order to keep its pace with other MNEs. Clearly, the only way for the BG-affiliated MNE to survive in the competition with incumbent multinationals is to develop superior advantages (Garg \& Delios, 2007)

Proposition 4: The bundling of BGAs, SSAs and CSAs by business group affiliates and their foreign subsidiaries influence their overall competitiveness over time

\section{Discussions and implications for practice}

The foregoing sections provide the theoretical framework and explanation of the competitive advantages and international expansion of BGs and their affiliates. The objective is not to offer some general and empirical assumptions but rather as refinements and additional to the previous literature. The idea that there exist some advantages that are specific to BGs and their affiliates are mentioned in the literature; its entire conceptualization, however, is still incomplete; see, for example, Delios and 
Ma (2010) and Ramamurti (2012). In this paper, this is resolved by offering a unique and novel conceptualization through the concept of BGA and ALA, their dimensions, evolution, and potential value in the international expansion of the BG and their affiliates. Using these concepts does not only provide a thorough understanding on the nature of BGs, but it is also about their growth over time. Although the preceding sections have strong theoretical base, supplementing them with implications for practice adds more worth. The following operational suggestions can be adopted by emerging economy BG multinationals in their home and host economies.

Business groups operations in the developing and transitioning economies. Stable supply of capital and labor is the most important assets in the developing economies because of the severe imperfections of the labor and financial markets. The BGA in transaction costs can be applied by BGs in maintaining an internal capital and labor markets rather than depending on external sources. The BGs should encourage the interaction of their affiliates to ensure resilience and flexibility of all their resources. This approach will avoid different types of risks in capital, labor, and inputs; therefore, the internalization mechanism or the group internal market provides the competitive advantage to BGs over other firms. In Asian cases, BGs established their own banks, training schools, and supplier networks to operate efficiently above industry standards, which also made them took advantage of BGA in scale and scope.

Business groups operations in the advanced economies. Most of the emerging BGs need to enhance their global competitiveness. The challenge for them is to use their BGA in group managerial skills and experience to take advantage of global knowledge and supply chain. Some BGs were successful in using their group managerial skills to acquire and recombine knowledge assets from incumbent multinationals and host countries. This can be done by a group network exploration and exploitation with the special participation of their foreign subsidiaries and stakeholders in the host countries. This is evident in the case of Indian BGs, particularly in their operations in the advanced economies in Europe and the United Kingdom. Indian BGs usually retain the management team of the acquired high- technology businesses while making sure that their subsidiary managers learn from their practices including those related local operational practices and institutions. These practices will then be transferred to the whole BG to enhance and add to the group managerial skills and experience. This is the approach to maintain and expand the global operations of the BG.

\section{Conclusion}

This paper provides theoretical foundation on emerging economy BGs. Thus far, BGs are understood as domestic groups of interdependent firms, collaborating as well as competing with MNEs in their home country. They are not seen as international firms or global players despite their international activities in interregional markets and even in advanced economies. In this paper, it is argued that the key to understanding the advantages of BGs is the fundamental point of departure in explaining their international expansion and competitiveness. Therefore, this paper offers a new perspective in analyzing the competitive advantages of both domestic and international BGs. It builds on the interrelated theories of transaction cost economics, capabilities, and resource-based views and network theory. By demonstrating the theoretical grounding of the contextual advantages of BG-affiliated firms, this paper clarifies the nature of BGA, ALAs, and its position in the contemporary international business literature and strategy. Undeniably, this paper contributes to the advancement of the emerging economy literature by filling out the gap regarding the clarification of the characteristics and advantages of the emerging economy firms by illuminating the case of BGs. Also, the theoretical framework that is presented here offers a robust analysis of the internal relationships, capabilities, and dynamics of the BG affiliates, regardless of the kind of economy that they are in, that is, emerging or developed and domestic or across borders.

\section{References}

[1] Amsden, A.H., Hikino, T., 1994. Project execution capability, organizational know-how 
and conglomerate corporate growth in late industrialization. Industrial and Corporate Change, 3(1), p.111.

[2] Barney, J., 1991. Firm resources and sustained competitive advantage. Journal of Management, 17(1), pp.99-120.

[3] Birkinshaw, J., Hood, N., Jonsson, S., 1998. Building firm-specific advantages in multinational corporations: the role of subsidiary initiative. Strategic Management Journal, 19(3), pp.221-242.

[4] Bonaglia, F., Goldstein, A., Mathews, J.A., 2007. Accelerated internationalization by emerging markets' multinationals: The case of the white goods sector. Journal of World Business, 42(4), pp.369-383.

[5] Buckley, P., Cross, A., Tan, H., Xin, L., Voss, H., 2008. Historic and emergent trends in Chinese outward direct investment. Management International Review, 48(6), pp.715-748.

[6] Carney, M., Gedajlovic, E., Heugens, P., Van Essen, M., Van Oosterhout, J., 2011. Business group affiliation, performance, con-text, and strategy: a meta-analysis. Academy of Management Journal, 54(3), pp.437-460.

[7] Chacar, A., Vissa, B., 2005. Are Emerging Economies Less Efficient? Performance Persistence and the Impact of Business Group Affiliation. Strategic Management Journal, 26(10), pp.933-946.

[8] Chandler, A.D., 1990. Scale and scope: Cambridge Univ Press.

[9] Chang, S.J., 2006. Business groups in East Asia: Post-crisis restructuring and new growth. Asia Pacific Journal of Management, 23(4), 407-417.

[10] Chang, S.J., Choi, U., 1988. Strategy, structure and performance of Korean business groups: A transactions cost approach. The Journal of Industrial Economics, pp.141-158.

[11] Chang, S.J., Hong, J., 2000. Economic performance of group-affiliated companies in Korea: Intragroup resource sharing and internal business transactions. Academy of Management Journal, pp.429-448.

[12] Chittoor, R., Ray, S., 2007. Internatio-nalization paths of Indian pharma-ceutical firms - A strategic group analysis. Journal of International Manage-ment, 13(3), pp.338-355.
[13] Colpan, A., Hikino, T., 2010. Foundations of Business Groups: Towards an Integrated Framework In A. M. Colpan, J. R. Lincoln \& T. Hikino (Eds.), The Oxford handbook of business groups: Oxford Univ Pr.

[14] Colpan, A., Hikino, T., Lincoln, J., 2010. The Oxford handbook of business groups: Oxford Univ Pr.

[15] Contractor, F., 2013. Punching above their weight. International Journal of Emerging Markets, 8(4), 304-328.

[16] Cuervo-Cazurra, A., Genc, M., 2008. Transforming disadvantages into advantages: developing -country MNEs in the least developed countries. Journal of International Business Studies, 39(6), pp.957-979.

[17] Cuervo-Cazurra, A., 2012. Extending theory by analyzing developing country multinational companies: solving the goldilocks debate. Global Strategy Journal, 2(3), pp.153-167.

[18] Delios, A., Ma, X., 2010. Diversification strategy and business groups. In A.M. Colpan, T. Hikino, J.R. Lincoln (Eds.). The Oxford Handbook of Business Groups, pp.718-742. Oxford: Oxford University Press.

[19] Demsetz, H., 1988. Theory of the Firm Revisisted, The. Journal of Law, Economics \& Organization, 4, p.141.

[20] Dierickx, I., Cool, K., 1989. Asset stock accumulation and sustainability of competitive advantage. Management Science, 35(12), pp.1504-1511.

[21] Douma, S., George, R., Kabir, R., 2006. Foreign and domestic ownership, business groups, and firm performance: evidence from a large emerging market. Strategic Management Journal, 27(7), pp.637-657.

[22] Dunning, J., 1980. Towards an eclectic theory of international production: some empirical tests. Journal of International Business Studies, 11(1), pp.9-31.

[23] Dunning, J., 2000. The eclectic paradigm of international production. The Nature of the Transnational Firm, p.119.

[24] Dyer, J., Singh, H., 1998. The relational view: Cooperative strategy and sources of interorganizational competitive advantage. Academy of Management Review, 23(4), pp.660-679. 
[25] Elango, B., Pattnaik, C., 2007. Building Capabilities for International Operations through Networks: A Study of Indian Firms. Journal of International Business Studies, 38(4), pp.541555.

[26] Erramilli, M.K., Agarwal, S., Kim, S.-S., 1997. Are firm-specific advantages location-specific too? Journal of International Business Studies, pp.735-757.

[27] Gammeltoft, P., Barnard, H., Madhok, A., 2010. Emerging multinationals, emerging theory: Macro- and micro-level perspectives. Journal of International Management, 16(2), pp.95-101.

[28] Garg, M., Delios, A., 2007. Survival of the foreign subsidiaries of TMNCs: The influence of business group affiliation. Journal of International Management, 13(3), pp.278-295.

[29] Ghemawat, P., Khanna, T., 1998. The nature of diversified business groups: A research design and two case studies. The Journal of Industrial Economics, 46(1), pp.35-61.

[30] Goldstein, A.E., Wells, L.T., 2007. Multinational companies from emerging economies: composition, conceptualization and direction in the global economy: Palgrave Macmillan New York.

[31] Gonenc, H., Kan, O., Karadagli, E. (2007). Business Groups and Internal Capital Markets. Emerging Markets Finance \& Trade, 43(2), pp.63-81.

[32] Granovetter, M., 1995. Coase revisited: business groups in the modern economy. Industrial and Corporate Change, 4, pp.93-130.

[33] Guillén, M.F., 2000. Business groups in emerging economies: a resource-based view. Academy of Management Journal, 43, pp.362380.

[34] Henisz, W.J., 2003. The Power of the Buckley and Casson Thesis: The Ability to Manage Institutional Idiosyncrasies. Journal of International Business Studies, 34(2), pp.173-184.

[35] Hennart, J.F., 1982. A Theory of Multinational Enterprise. Ann Arbor: University of Michigan Press.

[36] Hennart, J.F., 2009. Down with MNE centric theories! Market entry and expansion as the bundling of MNE and local assets. Journal of International Business Studies, 40, pp.14321454.
[37] Heugens, P., Zyglidopoulos, S., 2008. From social ties to embedded competencies: the case of business groups. Journal of Management \& Governance, 12(4), pp.325-341.

[38] Hobday, M., 1995. East Asian latecomer firms: learning the technology of electronics. World Development, 23(7), pp.1171-1193.

[39] Hymer, S.,1976. The international operations of national firms: A study of Direct Foreign Investment. Cambridge, MA: MIT Press.

[40] Johanson, J., Vahlne, J.E., 1977. The Internationalization Process of the Firm-A Model of Knowledge Development and Increasing Foreign Market Commitments. Journal of International Business Studies, 8(1), pp.23-32.

[41] Khanna, T., Palepu, K., 1997. Why focused strategies may be wrong for emerging markets. Harvard Business Review, 75(4), pp.41-51.

[42] Khanna, T., Palepu, K., 2000. The future of business groups in emerging markets: longrun evidence from Chile. Academy of Management Journal, 43, pp.268-285.

[43] Khanna, T., Rivkin, J., 2001. Estimating the performance effects of business groups in emerging markets. Strategic Management Journal, 22(1), pp.45-74.

[44] Kim, H., Hoskisson, R., Tihanyi, L., Hong, J., 2004. The evolution and restructuring of diversified business groups in emerging markets: The lessons from chaebols in Korea. Asia Pacific Journal of Management, 21(1), pp.25-48.

[45] Kock, C.J., Guillén, M.F., 2001. Strategy and structure in developing countries: Business groups as an evolutionary response to opportunities for unrelated diversification. Industrial and Corporate Change, 10(1), pp.77113.

[46] Kumaraswamy, A., Mudambi, R., Saranga, H., Tripathy, A., 2012. Catch-up strategies in the Indian auto components industry: Domestic firms/' responses to market liberalization. $J$ Int Bus Stud, 43(4), pp.368-395.

[47] Lavie, D., 2006. The competitive advantage of interconnected firms: an extension of the resource-based view. Academy of Manage-ment Review, 31(3), pp.638-658.

[48] Leff, N., 1978. Industrial Organization and Entrepreneurship in the Developing Countries: 
The Economic Groups. Economic Develop-ment \& Cultural Change, 26(4), pp.661.

[49] Leibenstein, H., 1968. Entrepreneurship and development. The American Economic Review, 58(2), pp.72-83.

[50] Li, P.P., 2007. Toward an integrated theory of multinational evolution: The evidence of Chinese multinational enterprises as late-comers. Journal of International Management, 13(3), pp.296-318.

[51] Luo, Y., Tung, R.L., 2007. International Expansion of Emerging Market Enterprises: A Springboard Perspective. Journal of International Business Studies, 38(4), pp.481-498.

[52] Mahmood, I., Mitchell, W., Chung, C., 2006. The Structure of Intra-Group Ties: Innovation in Taiwanese Business Groups.

[53] Mahmood, I., Zhu, H., Zajac, E., 2011. Where can capabilities come from? network ties and capability acquisition in business groups. Strategic Management Journal, 32(8), pp.820848.

[54] Pananond, P., Zeithaml, C., 1998. The International Expansion Process of MNEs from Developing Countries: A Case Study of Thailand's CP Group. Asia Pacific Journal of Management, 15(2), pp.163-184.

[55] Penrose, E., 1959. The theory of the growth of the firm: Oxford.

[56] Ramamurti, R., 2012. What is really different about emerging market multinationals? Global Strategy Journal, 2(1), pp.41-47.

[57] Ramamurti, R., Singh, J., 2009. Emerging multinationals in emerging markets: Cambridge University Press Cambridge.

[58] Rugman, A., 1981. Inside the multinationals: the economics of the multinational enterprise: Columbia University Press, New York.

[59] Rugman, A., 2009. Theoretical aspects of MNEs from emerging markets. In R. Ramamurti \& J. V. Singh (eds.), Emerging multinationals in emerging markets: Cambridge University Press Cambridge.

[60] Rugman, A., D'Cruz, J.R., 2000. Multinationals as flagship firms: Regional business networks: Oxford University Press, USA.

[61] Rugman, A., Verbeke, A., 1992. A note on the transnational solution and the transaction cost theory of multinational strategic management.
Journal of International Business Studies, 23(4), pp.761-771.

[62] Strachan, H., 1976. Family and other business groups in economic development: the case of Nicaragua. New York: Praeger.

[63] Tan, D., Meyer, K., 2010). Business groups' outward FDI: A managerial resources perspective. Journal of International Management, 16(2), pp.154-164.

[64] Teece, D., 2014. A dynamic capabilities-based entrepreneurial theory of the multinational enterprise. Journal of International Business Studies, 45(1), pp.8-37.

[65] Teece, D., Pisano, G., Shuen, A., 1997. Dynamic capabilities and strategic mana-gement. Strategic Management Journal, 18(7), pp.509-533.

[66] UNCTAD, 2010. World Investment Report. New York: United Nations.

[67] Verbeke, A., 2009. International business strategy: Rethinking the foundations of global corporate success. Cambridge University Press.

[68] Williamson, O.E., 1981. The economics of organization: The transaction cost approach. American Journal of Sociology, pp.548-577.

[69] Witt, M.A., Lewin, A.Y., 2007. Outward Foreign Direct Investment as Escape Response to Home Country Institutional Constraints. Journal of International Business Studies, 38(4), pp.579-594.

[70] Yaprak, A., Karademir, B., 2010. The internationalization of emerging market business groups: an integrated literature review. International Marketing Review, 27(2), pp.245262.

[71] Yiu, D.W., 2011. Multinational advantages of Chinese business groups: A theoretical exploration. Management and organization review, 7(2), pp.249-277.

[72] Yiu, D. W., Lu, Y., Bruton, G.D., Hoskisson, R.E., 2007. Business Groups: An Integrated Model to Focus Future Research. Journal of Management Studies, 44(8), pp.1551-1579.

[73] Zaheer, S., 1995. Overcoming the liability of foreignness. Academy of Management Journal, 38(2), pp.341-363. 